\title{
Residual effect of biochar and summer legumes on soil physical properties and wheat growth
}

\author{
Hafeez Ur Rahim ${ }^{1 *}$, Ishaq Ahmad Mian ${ }^{1}$, Muhammad Arif ${ }^{2}$, Zia Ur \\ Rahim $^{3}$, Sajjad Ahmad ${ }^{2}$, Zaid Khan ${ }^{2}$, Laiq Zada ${ }^{1}$, Muhammad Ayoub \\ $\mathrm{Khan}^{4}$ and Muhammad Haris ${ }^{1}$
}

1. Department of Soil \& Environmental Sciences, The University of Agriculture Peshawar-Pakistan

2. Department of Agronomy, The University of Agriculture Peshawar-Pakistan

3. Department of Zoology, University of Buner, KP-Pakistan

4. Department of Plant Breeding \& Genetics, The University of Agriculture Peshawar-Pakistan

*Corresponding author's email: hafeez.kalpani@aup.edu.pk

Citation

Hafeez Ur Rahim, Ishaq Ahmad Mian, Muhammad Arif, Zia Ur Rahim, Sajjad Ahmad, Zaid Khan, Laiq Zada, Muhammad Ayoub Khan, Muhammad Haris. Residual effect of biochar and summer legumes on soil physical properties and wheat growth. Pure and Applied Biology. Vol. 8, Issue 1, pp16-26.

http://dx.doi.org/10.19045/bspab.2018.700159

\begin{tabular}{|c|c|c|c|}
\hline Received: $16 / 07 / 2018$ & Revised: 24/09/2018 & Accepted: 29/09/2018 & Online First: 04/10/2018 \\
\hline
\end{tabular}

\section{Abstract}

Biochar, a carbon-rich solid material and legumes having numerous benefits to the soil-plant system gaining a keen interest as an innovative sustainable approach among the agriculture research community in many parts of the world especially in developing countries in order to enhance soil quality and ensure food security. Thus, with the same approach, we have carried out a field experiment to examine the residual effect of biochar application and summer legumes on soil physical properties and subsequent wheat crop growth at the Research Farm, The University of Agriculture Peshawar during winter 2016-2017. An experiment was designed in two-factor factorial randomized complete block design with three replications in summer 2016 in which three different summer legumes i.e. mungbean, sesbania, and cowpea were grown in the summer for the purpose of grain, green manuring and fodder, a fallow was also included with the purpose of control. Biochar was applied at the rate of 0,5 and 10 tons ha $^{-1}$. After the harvesting of summer legumes, sesbania biomass was completely incorporated into the soil while the biomass of other two legumes were removed. The experiment on subsequent wheat was on the same field layout of summer legumes. Both the treatments i.e. previously applied biochar especially 10 tons ha ${ }^{-1}$ and preceding summer legumes especially sesbania as well as their interaction showed a significant effect on the selected soil physical properties. Similarly, the response of wheat growth was also significant to both treatments but their interaction was non-significant. Thus, it was concluded that both the treatments had a significant effect on the soil physical properties and growth of wheat and should be included in the cropping system.

Keywords: Biochar; soil physical properties; summer legumes; wheat growth

\section{Introduction}

The growing global posterity is supposed to surely face the supreme challenge of food security; particularly, the advancing nations have greater threats for food security because they lack natural resources or severe degradation specifically of fertile soil and water. Soil degradation and nutrient depletion are global concerns and soil restoration techniques are greatly needed to 
increase soil organic matter (SOM), and stability of soil organic carbon (C) are required to increase productivity and minimize risks of soil degradation and environmental pollution. To this end, impacts of a range of agricultural, industrial byproducts (waste materials) and composts have been studied as soil amendments to enhance soil physical properties [1, 2], availability of plant nutrients [3]. So keeping in consideration the importance of soil resources for the maximum crop yield and growth and management of environmental pollutions, the biochar is gaining a keen interest among the scientists as a sustainable technique to get the desired objectives.

Biochar is a carbon-rich, fine-grained, a porous substance produced under oxygenlimiting conditions [4] at temperatures between 350 and $700{ }^{0} \mathrm{C}$. It can be defined as the solid residue obtained from the thermochemical decomposition or pyrolysis of plant and waste feedstock's, and can be specifically used for application to the soil as part of an agronomic or environmental management plan [5]. It can alter the physical properties of the soil such as structure, porosity, density, aeration, soil workability, water holding capacity and hence the growth of the plant [6].

Sustainable agricultural practices i.e. inclusion of biochar, legumes, compost, cover crops and other organic amendments are the ways of raising food that is healthy for consumers and animals without causing damage to ecosystem health. Low nutrient content and accelerated mineralization of soil organic matter (SOM) are the two major constraints currently encountered in sustainable agriculture renner [7]. Nutrients are retained in the soil and remain available to crops mainly by adsorption to minerals and soil organic matter. Usually, the addition of organic matter such as compost and manure into the soil can help retain nutrients. Biochar is considered much more effective than other organic matter in retaining and making nutrients available to plants. Its surface area and complex pore structure are hospitable to bacteria and fungi that plants need to absorb nutrients from the soil. Moreover, biochar is a more stable nutrient source than compost and manure [8].

\section{Materials and methods}

A rotation experiment was conducted in summer 2016 in which three legumes crops i.e. mungbean, sesbania, and cowpea were grown in the summer for the purpose of grain, green manuring and fodder, a fallow was also adjusted for the purpose of control. Biochar was added at the rate of 0,5 and 10 tons $\mathrm{ha}^{-1}$. The details of the treatment combinations as applied to the soil is presented in (Table 1). After the harvesting of summer legumes, sesbania biomass was thoroughly incorporated into the soil while the biomass of mungbean and cowpea were removed. The field experiment on the subsequent wheat was carried out in winter 2017 on two-factor factorial randomized complete block design having three replications on the same field layout of previous summer legumes. The plot size was $13.5 \times 4.2 \mathrm{~m}^{2}$ and wheat variety Pir Sabaq-2013 was sown at the rate of $120 \mathrm{~kg}$ $\mathrm{ha}^{-1}$. Soil samples were collected in proper moisture condition after subsequent wheat crop harvesting from each treatment plots and were analyzed for various soil physical properties such as organic matter, bulk density, saturation percentage and water holding capacity. The row to row distance for wheat was kept at $30 \mathrm{~cm}$. Basel dose of $\mathrm{N}$ at the rate of $120 \mathrm{~kg} \mathrm{~N} \mathrm{ha}^{-1}, \mathrm{P}$ at the rate of 90 $\mathrm{kg} \mathrm{P}_{2} \mathrm{O}_{5} \mathrm{ha}^{-1}$ and $\mathrm{K}$ at the rate of $60 \mathrm{~kg} \mathrm{~K}_{2} \mathrm{O}$ $\mathrm{ha}^{-1}$ were added in the form of Urea, DAP, and MOP, respectively, to each plot. $\mathrm{N}$ was added in two doses, half at the time of sowing and half at the vegetative stage of the crop, whereas all the $\mathrm{P}$ and $\mathrm{K}$ have been applied at sowing time.

Factors along their levels are presented below 
Factor A: Legumes grown in summer

1. Mungbean were added for food grain

2. Cowpea for forage

3. Sesbania for green manuring

4. Fallow as a control
Factor B: Biochar

1. 0 tons ha ${ }^{-1}$ (control)

2. 5 tons ha-1

3. 10 tons ha $^{-1}$

Table 1. Details of the treatment combinations as applied to the soil

\begin{tabular}{|c|c|}
\hline M0 $=$ Mungbean +0 tons ha $^{-1}$ Biochar & S0 $=$ Sesbania +0 tons ha $^{-1}$ Biochar \\
\hline M1 = Mungbean +5 tons ha ${ }^{-1}$ Biochar & $\mathrm{S} 1=$ Sesbania +5 tons ha $^{-1}$ Biochar \\
\hline M2 $=$ Mungbean +10 tons ha $^{-1}$ Biochar & $\mathrm{S} 2=$ Sesbania +10 tons ha $^{-1}$ Biochar \\
\hline $\mathrm{C} 0=$ Cowpea +0 tons ha ${ }^{-1}$ Biochar & $\mathrm{F} 0=$ Fallow +0 tons ha ${ }^{-1}$ Biochar \\
\hline $\mathrm{C} 1=$ Cowpea +5 tons ha ${ }^{-1}$ Biochar & $\mathrm{F} 1=$ Fallow +5 tons ha $^{-1}$ Biochar \\
\hline $\mathrm{C} 2=$ Cowpea +10 tons $^{-1}$ Biochar & $\mathrm{F} 2=$ Fallow +10 tons ha $^{-1}$ Biochar \\
\hline
\end{tabular}

Data was recorded on the following parameters

\section{Soil organic matter $(\%)$}

In soil samples, organic matter was determined by the method of Walkley-Black as expounded by Nelson and Sommers [9], by using the formula.

$\operatorname{SOM}(\%)=\left[\left(\mathrm{mL}\right.\right.$ of $\left.\mathrm{K}_{2} \underline{\mathrm{Cr}}_{2} \underline{\mathrm{O}}_{7} \times \mathrm{N}\right)-\left(\mathrm{mL}\right.$ of $\mathrm{FeSO}_{4}$ $\left.\left..7 \mathrm{H}_{2} \mathrm{Ox} \mathrm{N}\right)\right] \times 0.69$

Weight of soil (g)

Soil bulk density $\left(\mathrm{g} \mathrm{cm}^{-3}\right)$

Blake and Hartge [10] method was used for the measurement of bulk density by using the given formula.

$\mathrm{BD}=\frac{\mathrm{M}}{\mathrm{V}}$

Soil Saturation percentage $(\%)$

The saturation percentage was determined by the procedure as described by Gardner [11], with the help of formula.

Saturation water percentage $(\mathrm{sPw})=$ $\frac{\text { Mt-Ms }}{\text { Ms }} \times 100$

\section{Water holding capacity (\%)}

Available water holding capacity was determined in soil samples by the procedure as mentioned by Raza et al. [12]

Formula: $\Psi=\mathrm{a} \omega^{\mathrm{b}}$

\section{Plant height (cm)}

The plant height of wheat was recorded with the help of measuring tape on selected ten plants randomly in two central rows of each and every treatment plots.

\section{Number of grains spike $e^{-1}$}

Data regarding the number of grains spike ${ }^{-1}$ were recorded by counting the number of grains for five representative spikes in each subplot. Spikes of various sizes were randomly chosen and threshed separately. Number of the grains were counted and averaged.

\section{Spikes $\mathbf{m}^{-2}$}

Data regarding spikes $\mathrm{m}^{-2}$ was recorded by counting the total number of spikes in one meter area in three central rows of each subplot and converted into the number of spikes $\mathrm{m}^{-2}$ by using the following formula: Spike $\mathrm{m}^{-2}=\frac{\text { No.of spikes counted }}{\mathrm{R}-\mathrm{R} \text { distance } \times \text { Row length } \times \text { No.of rows selected }}$

\section{Spike length (cm)}

Five spikes in each subplot were randomly selected; spike length was measured with the help of measuring tape from the base of spike and to the tip of the awn. Average spike length was then calculated.

\section{Results and discussion}

\section{Soil Organic Matter (\%)}

The data concerning soil organic matter content as affected by the residual application of biochar and summer legumes are given in (Table 2 \& Figure 1). Mean Values of the data revealed that previously applied biochar and legumes sown in summer significantly affected $(\mathrm{p} \leq 0.05)$ soil organic matter. The legumes and biochar interaction was also significant for the organic matter. The soil organic matter was considerably affected by 
preceding legumes. The maximum soil organic matter $(0.85 \%)$ was recorded in the plots incorporated with sesbania followed by cowpea $(0.80 \%)$ and mungbean $(0.73 \%)$. The lowest soil organic matter $(0.47 \%)$ was recorded in the plots previously kept fallow. Similarly, in the case of biochar, the maximum soil organic matter $(0.96 \%)$ was recorded in the plots previously received biochar at the rate of 10 tons $\mathrm{ha}^{-1}$ followed by 5 tons $\mathrm{ha}^{-1}(0.70 \%)$, while the minimum soil organic matter $(0.48 \%)$ was recorded in the plots previously received biochar at the rate of 0 tons $\mathrm{ha}^{-1}$. Shah et al. [13] reported that soil organic fertility after green manuring of summer legumes in summer of 2002 showed that the soil organic fertility was consistently higher in legumes than in fallow plot. Our results are also in accordance with Jensen et al. [14] who reported that legumes inclusion can increase humus, soil organic carbon content, improve structure and water holding capacity of the soil. Chaudhry et al. [15] reported that highest soil organic matter content was observed for the treatment having biochar application alone and the lowest organic matter content was noticed for the treatment receiving inorganic fertilizer without biochar amendment. Addition of biochar to the agricultural soil is important for the carbon sequestration and soil organic fertility, and having residence time for millions of years in the soil reported by Kumar et al. [16].Our results are also in accordance with Ali et al. [17], Pattanayak et al. [18] and Sarwar et al. [19].

\section{Soil bulk density $\left(\mathrm{gcm}^{-3}\right)$}

The data concerning the bulk density of soil as influenced by the residual application of biochar and summer legumes are shown in (Table $2 \&$ Figure 2). Mean values of the data revealed that both previously applied biochar and preceding legumes considerably affected the bulk density of soil. All the interactions were also significant $(p \leq 0.05)$. The soil bulk density was considerably affected by preceding legumes. The lowest soil bulk density $\left(1.13 \mathrm{~g} \mathrm{~cm}^{-3}\right)$ was noticed in the plot previously sown with sesbania followed by mungbean $\left(1.19 \mathrm{~g} \mathrm{~cm}^{-3}\right)$ and cowpea $(1.21 \mathrm{~g}$ $\left.\mathrm{cm}^{-3}\right)$, while the highest bulk density $\quad(1.23$ $\mathrm{g} \mathrm{cm}^{-3}$ ) was observed in the fallow plots. Similarly, in case of biochar, the minimum bulk density of soil $1.14 \mathrm{~g} \mathrm{~cm}^{-3}$ has been observed for the treatment having biochar at the rate of 10 tons $\mathrm{ha}^{-1}$ followed by $1.19 \mathrm{~g} \mathrm{~cm}^{-}$ 3 for the treatment received 5 tons $\mathrm{ha}^{-1}$ biochar. The highest soil bulk density of 1.25 $\mathrm{g} \mathrm{cm}^{-3}$ was noticed in the control plots. A reduce bulk density of soil having treatment of sesbania is probably associated with the greater amount of soil organic matter deposition and loosening of soil by root action, these results were reported by Lampurlanes and Martinez [20]. Similarly, Chikowo et al. [21] published that addition of woody legumes to the soil reduces bulk density and increases soil granulation and porosity. Alike results were also given by Haynes, [22]. Quin et al. [23] reported that biochar prepared from woody residues had a higher effect on bulk density in a coarsetextured soil than in soils having a higher amount of clay content. Our results are also in support of the Laird et al. [24] who reviewed that biochar-amended soil after 500 days even applied in lower amount have recorded large decrease in bulk density of soil. Same results have also been reported by Chaudhry et al. [15].

\section{Soil saturation percentage $(\%)$}

Average values of the data stated that preceding legumes and previously applied biochar significantly affected $(\mathrm{p} \leq 0.05)$ saturation percentage as shown in (Table $2 \&$ Figure 3). The legumes and biochar interaction were also significant for the saturation percentage. Maximum saturation percentage $(52.3 \%)$ was noticed in the plots incorporated with sesbania followed by cowpea (48.1\%) and mungbean (46.2\%), while the lowest soil saturation percentage 
$(42.6 \%)$ was recorded in the fallow plots. In case of biochar, the maximum soil saturation percentage $(51.0 \%)$ was noticed in the treatments plots previously received biochar at the rate of 10 tons $\mathrm{ha}^{-1}$ followed by 5 tons ha $^{-1}(47.4 \%)$, while the minimum saturation percentage $(43.5 \%)$ was noticed in the plots previously received biochar at the rate of 0 tons $\mathrm{ha}^{-1}$. Sultani et al. [25] reported that green manuring crops significantly reduced bulk density, enhanced total porosity, increased available water holding capacity, and also increase the water retention in the soil. Our results were also confirmed by the observation of (Carlson and Huss-Danell, [26]; Mayer et al. [27] who found that green manuring legumes as compared to nonlegumes significantly increase aeration, porosity, and moisture retention capacity of the soil. Atkinson et al. [28]; Major et al. [29] reported that application of biochar to the soil improves a wide range of physical properties of the soil such as total porosity, moisture content, saturation percentage, water holding capacity or plant available water content and hydraulic conductivity. Our results are also in agreement with Sohi et al. [30]; Zwieten et al. [31].

\section{Water holding capacity (\%)}

Preceding legumes and previously applied biochar significantly affected $(\mathrm{p} \leq 0.05)$ water holding capacity of the soil as shown in (Table 2 \& Figure 4). The legumes and biochar interaction were also significant. The maximum water holding capacity $(13.50 \%)$ was noted in the plots incorporated with sesbania followed by cowpea $(12.10 \%)$ and mungbean $(11.80 \%)$, while the lowest soil water holding capacity $(7.10 \%)$ was recorded in the fallow plots. In case of biochar, the maximum soil water holding capacity $(13.60 \%)$ was noted in the treatments plots previously received biochar at the rate of 10 tons $\mathrm{ha}^{-1}$ followed by 5 tons $\mathrm{ha}^{-1}(10.70 \%)$, while the minimum water holding capacity $(9.10 \%)$ was noticed in the plots previously received biochar at the rate of 0 tons ha ${ }^{-1}$. Sultani et al. [25] reported that green manuring crops significantly reduced bulk density, enhanced total porosity, increased available water holding capacity, and also increase the water retention in the soil. Our results were also confirmed by the observation of Carlson and Huss-Danell [26]; Mayer et al. [27] who found that green manuring legumes as compare to nonlegumes significantly increase aeration, porosity, and moisture retention capacity of the soil. Atkinson et al. [28]; Major et al. [27] reported that application of biochar to the soil improves a wide range of physical properties of the soil such as total porosity, moisture content, saturation percentage, water holding capacity or plant available water content and hydraulic conductivity. Our results are also in agreement with Sohi et al. [30]; Zwieten et al. [31].

\section{Plant height (cm)}

Statistical analysis of the data revealed that previously applied biochar and preceding legumes significantly affected $(\mathrm{p} \leq 0.05)$ plant height of wheat as shown in (Table 3). The legumes and biochar interaction was nonsignificant. The plots incorporated with sesbania produced the tallest plants $(101 \mathrm{~cm})$, followed by mungbean $(96.4 \mathrm{~cm})$ and cowpea $(96.1 \mathrm{~cm})$, while the fallow plot produced the shortest plants $(94.8 \mathrm{~cm})$ which were statistically at par with each other. In case of biochar, the tallest plant height $(98.3 \mathrm{~cm})$ were recorded in the plots where biochar was applied previously at the rate of 10 tons $\mathrm{ha}^{-1}$, which was statistically at par with 5 tons ha ${ }^{-1}$ $(97.9 \mathrm{~cm})$, while the plots previously received biochar at the rate of 0 tons $\mathrm{ha}^{-1}$ produced the shortest wheat plants $(95.2 \mathrm{~cm})$. Gerami et al. [32] reported that plant height of wheat is significantly affected by green manures as compare to no-green manures. This is due to the release of different macro and micronutrients specifically nitrogen from the residues of these green manures which 
have a positive effect on the stem elongation of subsequent crop. Similarly, Ali et al. [33] reported that plots previously sown with legumes (sesbania, cowpea, mungbean and fallow) have a significant effect on plant height which may be due to the residual soil fertility improved by the previous legumes. Olmo et al. [34] reported that plots treated with biochar improved soil characteristics, nutrients availability and consequently wheat growth. Same results were also reported by Liu et al. [4].

Table 2. Soil organic matter (SOM), bulk density (BD), saturation percentage (SP) and water holding capacity (WHC) as affected by residual application of biochar and summer legumes

\begin{tabular}{|c|c|c|c|c|}
\hline Legumes & S.O.M (\%) & B.D $\left.\mathbf{~ g ~ c m}^{-3}\right)$ & S.P (\%) & W.H.C (\%) \\
\hline Cowpea & $0.80 \mathrm{ab}$ & $1.21 \mathrm{ab}$ & $48.1 \mathrm{~b}$ & $12.10 \mathrm{ab}$ \\
\hline Mungbean & $0.73 \mathrm{~b}$ & $1.19 \mathrm{~b}$ & $46.2 \mathrm{c}$ & $11.80 \mathrm{~b}$ \\
\hline Sesbania & $0.85 \mathrm{a}$ & $1.13 \mathrm{c}$ & $52.3 \mathrm{a}$ & $13.50 \mathrm{a}$ \\
\hline Fallow & $0.47 \mathrm{c}$ & $1.23 \mathrm{a}$ & $42.6 \mathrm{~d}$ & $7.10 \mathrm{c}$ \\
\hline LSD $(0.05)$ & 0.074 & 0.020 & 1.15 & 1.20 \\
\hline Biochar $\left(\right.$ tons ha- $\left.^{-1}\right)$ & & & & \\
\hline 0 & $0.48 \mathrm{c}$ & $1.25 \mathrm{a}$ & $43.5 \mathrm{c}$ & $9.10 \mathrm{c}$ \\
\hline 5 & $0.70 \mathrm{~b}$ & $1.19 \mathrm{~b}$ & $47.4 \mathrm{~b}$ & $10.70 \mathrm{~b}$ \\
\hline 10 & $0.96 \mathrm{a}$ & $1.14 \mathrm{c}$ & $50.0 \mathrm{a}$ & $13.60 \mathrm{a}$ \\
\hline LSD $(0.05)$ & 0.064 & 0.017 & 0.99 & 1.03 \\
\hline Interaction & & & & $*$ \\
\hline L x B & $*$ & $*$ & $*$ & $*$ \\
\hline
\end{tabular}

Means followed by different letter(s) in the same column are significantly different from one another at $5 \%$ level of probability; $*$ = Significant at $5 \%$ level of probability, respectively

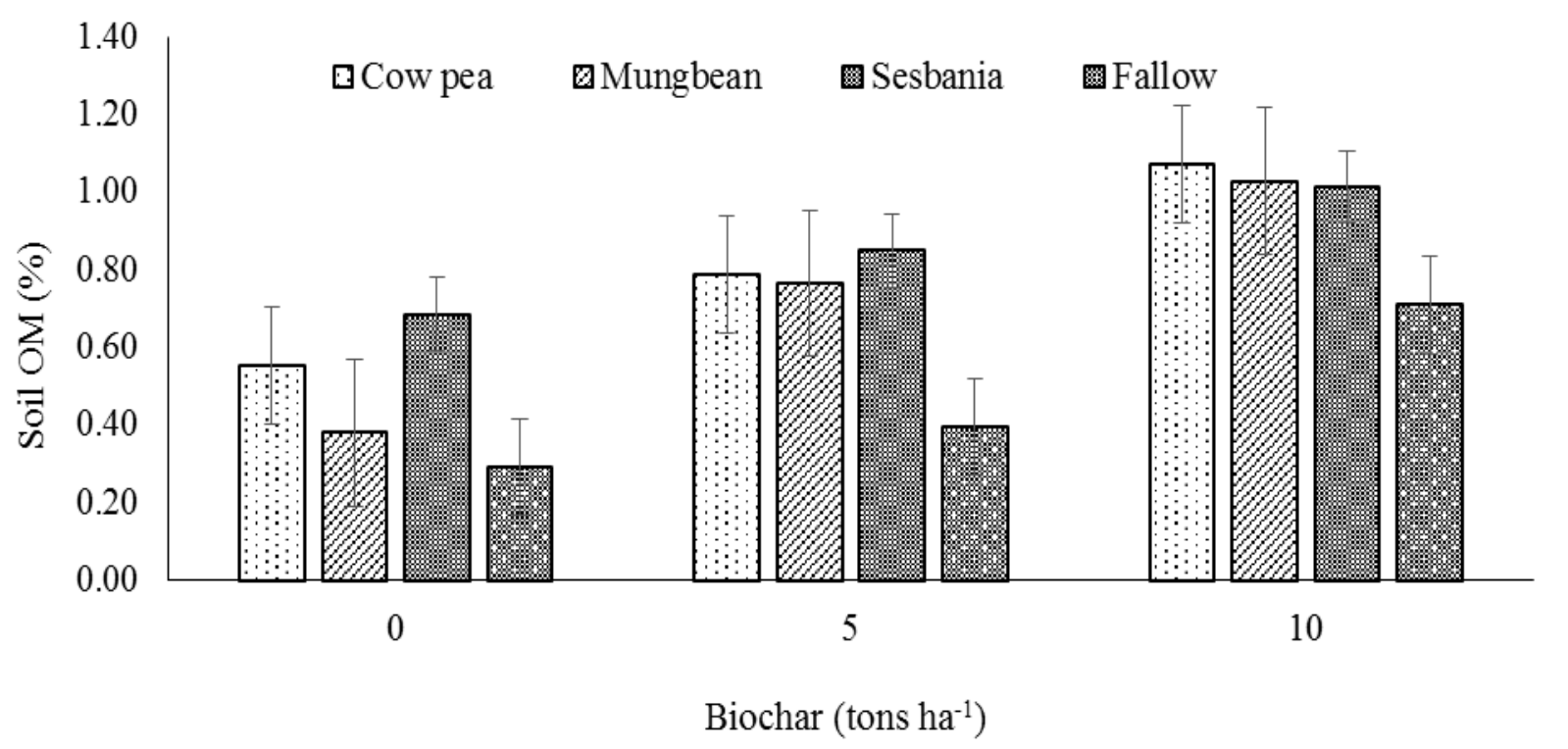

Figure 1. Soil organic matter (\%) content as influenced by residual application of biochar and summer legumes after wheat harvest 


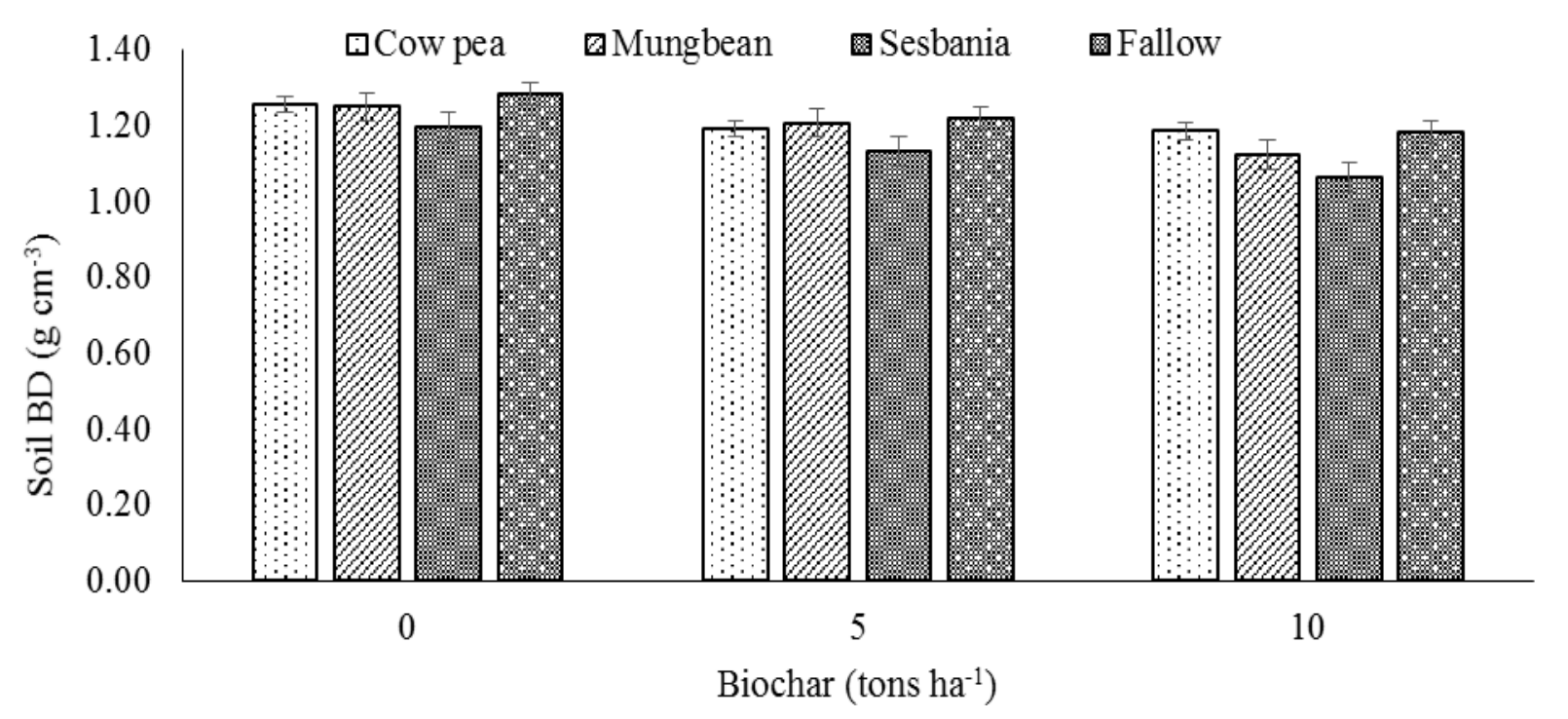

Figure 2. Soil bulk density $\left(\mathrm{g} \mathrm{cm}^{-3}\right)$ as influenced by residual application of biochar and summer legumes after wheat harvest

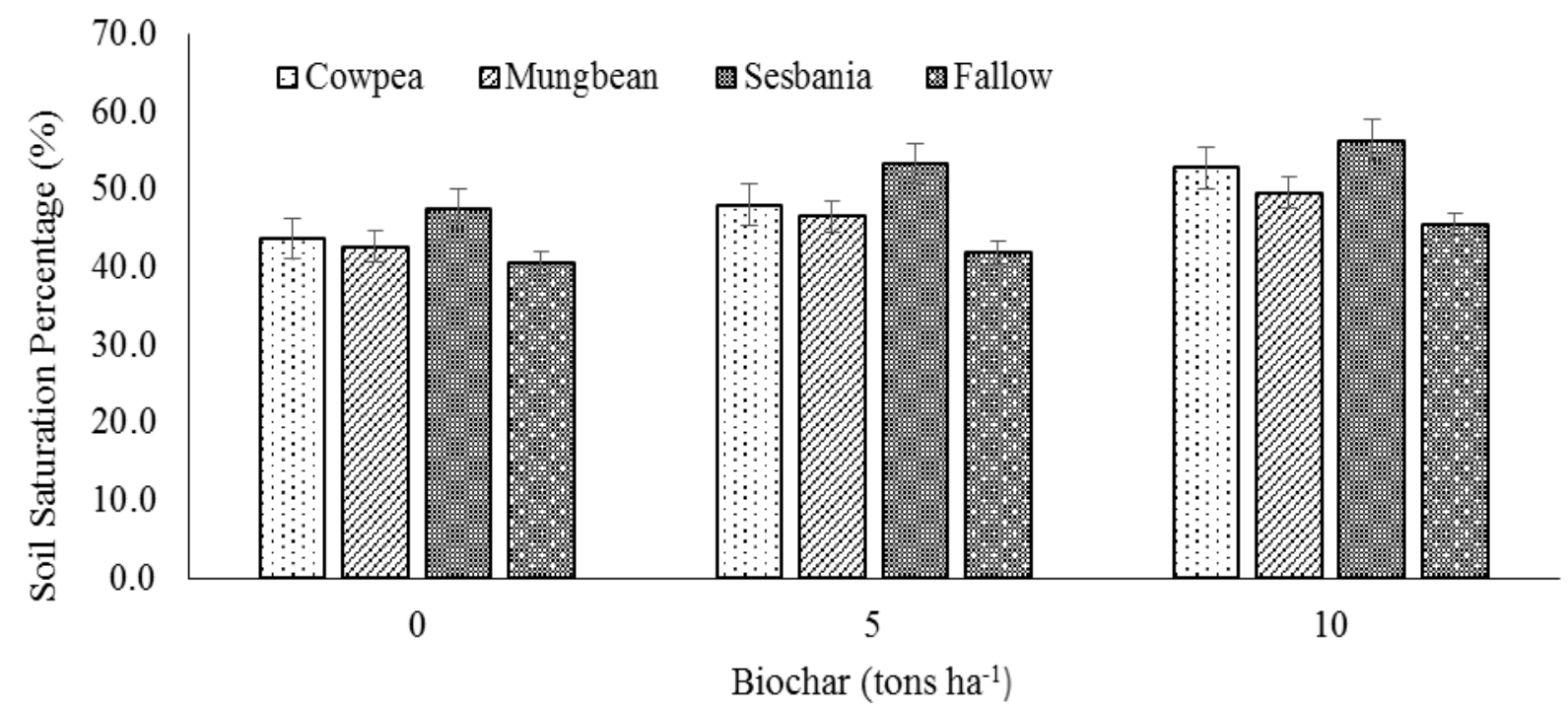

Figure 3. Soil Saturation percentage $(\%)$ as influenced by residual application of biochar and summer legumes after wheat harvest 


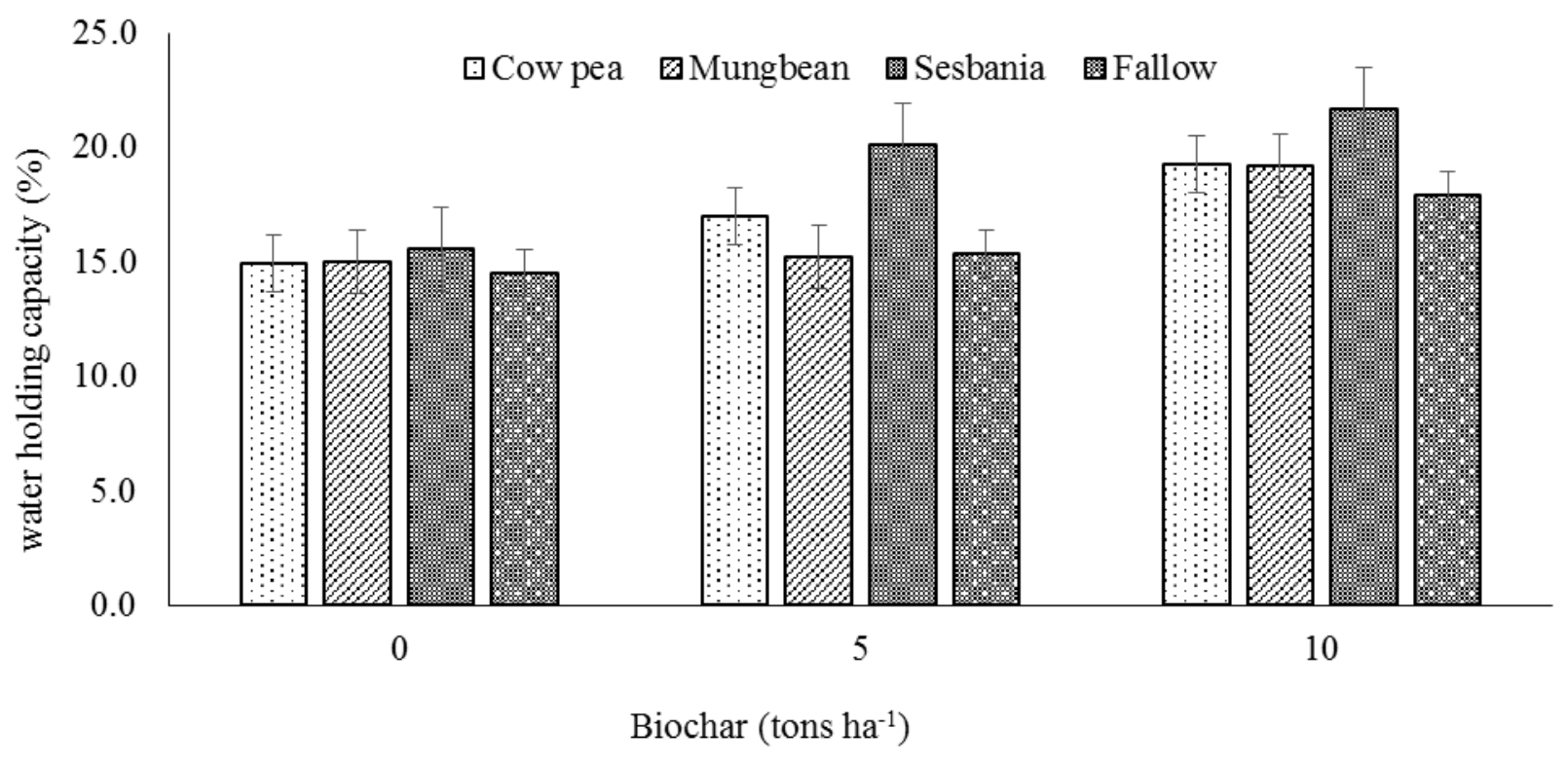

Figure 4. Water holding capacity (\%) as influenced by residual application of biocharand summer legumes after wheat harvest

\section{Grains spike ${ }^{-1}$}

Grains spike ${ }^{-1}$ of wheat as affected by the residual application of biochar and summer legumes are given in (Table 3). Statistical analysis of the data revealed that previously applied biochar and preceding legumes significantly affected $(p \leq 0.05)$ Grains spike 1 of the wheat crop. The legumes and biochar interaction was non-significant. The plots incorporated with sesbania produced the maximum number of grains spike ${ }^{-1}(50)$, followed by mungbean (47) and cowpea (47), while the fallow plot produced the minimum number of grains spike $^{-1}(46)$ which were statistically at par with each other. In case of biochar, the maximum number of grains spike $^{-1}$ (51) were recorded in the plots where biochar was applied previously at the rate of 10 tons $\mathrm{ha}^{-1}$, which was statistically at par with 5 tons $\mathrm{ha}^{-1}$ (48), while the plots previously received biochar at the rate of 0 tons $\mathrm{ha}^{-1}$ produced the minimum grains spike

${ }^{1}$ (45). Gerami et al. [32] reported that yield and growth parameters of wheat is significantly affected by green manures as compare to no-green manures. This is due to the release of different macro and micronutrients specifically nitrogen from the residues of these green manures which have a positive effect on the stem elongation of subsequent crop. Similarly, Ali et al. [33] reported that plots previously sown with legumes (sesbania, cowpea, mungbean and fallow) have a significant effect on plant grains spike $^{-1}$ which may be due to the residual soil fertility improved by the previous legumes. Olmo et al. [34] reported that plots treated with biochar improved soil characteristics, nutrients availability and consequently wheat growth. Same results were also reported by Liu et al. [4]. 


\section{Spikes $\mathbf{m}^{-2}$}

Spike $\mathrm{m}^{-2}$ of wheat as affected by the residual application of biochar and summer legumes are given in (Table 3 ). Previously applied biochar and preceding legumes significantly affected $(\mathrm{p} \leq 0.05)$ spike $\mathrm{m}^{-2}$ of the wheat crop. The legumes and biochar interaction was non-significant. The plots incorporated with sesbania produced the maximum number of Spike $\mathrm{m}^{-2}$ (322), followed by cowpea (303) and mungbean (299), while the fallow plot produced the minimum number of spike $\mathrm{m}^{-2}$ (291). In case of biochar, the maximum number of spike $\mathrm{m}^{-2}$ (318) were recorded in the plots where biochar was applied previously at the rate of 10 tons $\mathrm{ha}^{-1}$, followed by 5 tons ha ${ }^{-1}$ (306), while the plots previously received biochar at the rate of 0 tons $\mathrm{ha}^{-1}$ produced the minimum spike $\mathrm{m}^{-2}$
(287). Gerami et al. [32] reported that yield and growth parameters of wheat are significantly affected by green manures as compare to no-green manures. This is due to the release of different macro and micronutrients specifically nitrogen from the residues of these green manures which have a positive effect on the stem elongation of subsequent crop. Similarly, Ali et al. [33] reported that plots previously sown with legumes (sesbania, cowpea, mungbean and fallow) have a significant effect on plant grains spike $^{-1}$ which may be due to the residual soil fertility improved by the previous legumes. Olmo et al. [34] reported that plots treated with biochar improved soil characteristics, nutrients availability and consequently wheat growth. Same results were also reported by Liu et al. [4].

Table 3. Plant height, grains spike $\mathrm{e}^{-1}$ and spike $\mathrm{m}^{-2}$ as affected by residual application of biochar and summer legumes

\begin{tabular}{|c|c|c|c|}
\hline Legumes & Plant Height $(\mathrm{cm})$ & Grains Spike $^{-1}$ & Spike $\mathrm{m}^{-2}$ \\
\hline Cowpea & $96.1 \mathrm{~b}$ & $47 \mathrm{~b}$ & $303 \mathrm{~b}$ \\
\hline Mungbean & $96.4 \mathrm{~b}$ & $47 \mathrm{~b}$ & $299 \mathrm{~b}$ \\
\hline Sesbania & $101.4 \mathrm{a}$ & $50 \mathrm{a}$ & $322 \mathrm{a}$ \\
\hline Fallow & $94.8 \mathrm{~b}$ & $46 \mathrm{~b}$ & $291 c$ \\
\hline LSD (0.05) & 1.853 & 1.4 & 6.9 \\
\hline \multicolumn{4}{|c|}{ Biochar (tons ha') } \\
\hline 0 & $95.2 \mathrm{~b}$ & $45 \mathrm{c}$ & $287 \mathrm{c}$ \\
\hline 5 & $97.9 \mathrm{a}$ & $48 \mathrm{~b}$ & $306 \mathrm{~b}$ \\
\hline 10 & $98.3 \mathrm{a}$ & $51 \mathrm{a}$ & $318 \mathrm{a}$ \\
\hline LSD (0.05) & 1.604 & 1.19 & 5.9 \\
\hline \multicolumn{4}{|l|}{ Interaction } \\
\hline $\mathrm{L} \times \mathrm{B}$ & Ns & Ns & Ns \\
\hline
\end{tabular}

Means followed by different letter(s) in the same column are significantly different from one another at $5 \%$ level of probability; Ns= non-significant

\section{Conclusions}

On the basis of experimental results, it is concluded that residual application of biochar and preceding legumes had a significant effect on the soil physical properties and of growth of subsequent wheat. Previously applied biochar at the rate of 10 tons $\mathrm{ha}^{-1}$ and preceding legumes especially previously incorporated sesbania had a significant carryover effect on the soil physical properties and of growth of subsequent wheat. Similarly, the interactive effect of residual biochar application at the rate of 10 tons $\mathrm{ha}^{-1}$ with previously incorporated sesbania had a significant effect on the soil physical properties and of growth of subsequent wheat.

\section{Authors' contributions}

Conceived and designed the experiments: IA Mian \& HU Rahim, Performed the 
experiments: IA Mian, Analyzed the data: ZU Rahim, S Ahmad \& Z Khan, Contributed materials/ analysis/ tools: MA Khan, M Haris \& L Zada, Wrote the paper: IA Mian \& HU Rahim.

\section{Acknowledgements}

We greatly acknowledged the Post-Graduate Laboratory of the Department of Soil and Environmental Sciences, The University of Agriculture Peshawar for providing facilities for this research work.

\section{References}

1. Wells AT, Chan KY \& Cornish PS (2000). Comparison of conventional and alternative vegetable farming systems on the properties of a yellow earth in New South Wales. Agr Ecosyst Environ 80: 47-60.

2. Zebarth BJ, Neilsen GH, Hogue E \& Neilsen D (1999). Influence of organic waste amendments on selected soil physical and chemical properties. Can J Soil Sci 79: 501-504.

3. Tejada M, Dobao MM, Benitez C \& Gonzalez JL (2001). Study of composting of cotton residues. Bioresour Technol 79: 199202.

4. Liu X, Zhang A, Ji C, Joseph S, Bian R, Li L, Pan G \& Paz-Ferreiro J (2014). Biochar's effect on crop productivity and the dependence on experimental conditions-a meta-analysis of literature data. Plant and Soil 373(1-2): 583-594.

5. Lehmann J \& Joseph S (2009). Biochar for environmental management: an introduction. In: Lehmann J, and S. Joseph (eds). Biochar for environmental management: Sci and Technol Earthscan London 1-10.

6. Downie, A., A. Crosky, P. Munroe. (2009) Physical properties of biochar. In: Lehmann J, Joseph S (eds) Biochar for environmental management: science and technology. Earthscan, London 13-32.

7. Renner R (2007). Rethinking biochar.

8. Chan KY, Zwieten LV, Meszaros I, Downie A \& Joseph S (2008). Agronomic values of green waste biochar as a soil amendment. Soil Res 45(8): 629-634.
9. Nelson DW \& Sommers LE (1996). Total carbon, organic carbon, and organic matter. Methods of soil analysis part 3 chemical methods, (methodsofsoilan3), pp 961-1010.

10. Blake GR \& Hartage KH (1986). Bulk density. pp 364-366. In: G.S. Campbell, R.D. Jackson, M.M. Martland, D.R. Nielson, and A Klute (eds). Methods of soil Analysis part I. Am Soc Agron Inc Madison, Wisconsin, U.S.A.

11. Gardner WH (1986). Water content. Methods of Soil Analysis: Part 1 Physical and Mineralogical Methods, (methodsofsoilan1) 493-544.

12. Shah Z, Ahmad SR \& Rahman H (2011). Sustaining rice-wheat system through management of legumes I: effect of green manure legumes on rice yield and soil quality. Pak J Bot 43: 1569-1574.

13. Jensen ES, Peoples MB, Boddey RM, Gresshoff PM, Hauggaard-Nielsen H, Alves BJ \& Morrison MJ (2011). Legumes for mitigation of climate change and the provision of feedstock for biofuels and biorefineries. A review. Agronomy for Sustainable Devel 32(2): 329-364.

14. Chaudhry K, Shahzad US, Naqqash MN, Saboor A, Yaqoob S, Salim M \& Khalid $M$ (2016). Integration of biochar and chemical fertilizer to enhance quality of soil and wheat crop (Triticum aestivum L.). Peer J Pre Prints 4: 1631.

15. Kumar S, Masto RE, Ram LC, Sarkar P, George J \& Selvi VA (2013). Biochar preparation from Parthenium hysterophorus and its potential use in soil application. Ecol Engin (55): 67-72.

16. Ali K, Arif M, Jan MT, Khan MJ \& Jones GL (2015). Integrated use of biochar: a tool for improving soil and wheat quality of degraded soil under wheat-maize cropping pattern. Pak J Bot 47(1): 233240.

17. Ali K, Arif M, Jan MT, Yaseen T, Waqas M \& Munsif F (2015). Biochar: a novel tool to enhance wheat productivity and soil fertility on sustainable basis under wheatmaize-wheat cropping pattern. Pak J Bot 47(3): 1023-1031. 
18. Pattanayak, S.K., K.N. Mishra, M.K. Jena and R.K. Nayak. 2001. Evaluation of green manure crops fertilized with various phosphorus sources and their effect on subsequent rice crop. $J$ of the Indian Society of Soil Sci 49(2):285-291.

19. Sarwar G, Hussain N, Mujeeb F, Schmeisky H \& Hassan G (2003). Biocompost application for the improvement of soil characteristics and dry matter yield of Lolium perenne (Grass). Asian J Plant Sci 2(2): 237-241.

20. Lampurlanés CJ \& Martínez CC (2003). Soil bulk density and penetration resistance under different tillage and crop management systems and their relationship with barley root growth. Agronomy J 95(3):526-536.

21. Chikowo R, Mapfumo P, Nyamugafata $P$ $\&$ Giller KE (2004). Woody legume fallow productivity, biological N 2-fixation and residual benefits to two successive maize crops in Zimbabwe. Plant and Soil 262(1): 303-315.

22. Haynes RJ (2000). Interactions between soil organic matter status, cropping history, method of quantification and sample pretreatment and their effects on measured aggregate stability. Biol and Fertility of Soils 30(4): 270-275.

23. Quin, P.R., A.L. Cowie, R.J. Flavel, .B.P. Keen, L.M. Macdonald, S.G. Morris BP, Singh Young IM \& Van Zwieten L (2014). Oil mallee biochar improves soil structural properties-a study with x-ray micro-CT. Agri Ecosys \& Environ 191: 142-149.

24. Laird DA, Fleming P, Davis DD, Horton R, Wang B \& Karlen, DL (2010). Impact of biochar amendments on the quality of a typical Midwestern agricultural soil. Geoderma, 158(3): 443-449.

25. Sultani MI, Gill MA, Anwar MM \& Athar M (2007). Evaluation of soil physical properties as influenced by various green manuring legumes and phosphorus fertilization under rain fed conditions. Inter $J$ of Environ Sci \& Technol 4(1): 109-118.

26. Carlson G \& Danell KH (2003). Nitrogen fixation in perennial forage legumes in the field. Plant and Soil 253(2): 353-372.

27. Mayer, J., F. Buegger, E.S. Jensen, M. Schloter and J. Heß. 2003. Residual nitrogen contribution from grain legumes to succeeding wheat and rape and related microbial process. Plant and Soil. 255(2):541-554.

28. Atkinson, C.J., J.D. Fitzgerald and N.A. Hipps. 2010. Potential mechanisms for achieving agricultural benefits from biochar application to temperate soils: A review. Plant Soil. 337(1-2): 1-18.

29. Major J, Steiner C, Downie A \& Lehmann J (2009). Biochar effects on nutrient leaching. Biochar for environmental management: Sci and Technol 271.

30. Sohi, S., E. Lopez-Capel, E. Krull and R. Bol. 2009. Biochar, climate change and soil: A review to guide future research. CSIRO Land and Water Sci Rep 5(09): 1731.

31. Zwieten LV, Singh BP \& Cox J (2012). Chapter four: biochar effects on soil properties. Biochar in horticulture: prospects for the use of biochar in Australian horticulture. Horticulture Australia, NSW Department of Primary Industries.

32. Gerami F, Aynehb A \& Taherifard E (2013). The Influence of Legume and Non-Legume Green Manures Along with Nitrogen Fertilizer Levels on Some Traits of Wheat (Triticum aestivum L.) as Subsequent Crop.

33. Ali W, Jan A \& Abbas A (2015). Residual effect of preceding legumes and nitrogen levels on subsequent maize. Int J Agron and Agric Res 7(1): 78-85.

34. Olmo M, Lozano AM, Barrón V \& Villar R (2016). Spatial heterogeneity of soil biochar content affects soil quality and wheat growth and yield. Sci of the Total Environ (562): 690-700. 